\title{
Multiple Infantile Hepatic Hemangioendothelioma: Doppler \\ Ultrasonography and CT findings of a Case
}

\section{Multipl İnfaltil Hepatik Hemanjioendotelyoma: Bir vakanın Doppler Ultrasonografi ve BT bulguları}

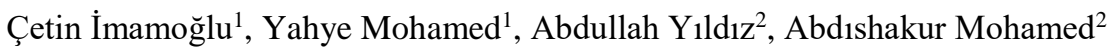 \\ ${ }^{1}$ Somali-Türkiye Recep Tayyip Erdoğan Eğitim Ve Araştırma Hastanesi, Radyoloji Kliniği, Mogadishu \\ ${ }^{2}$ Somali-Türkiye Recep Tayyip Erdoğan Eğitim Ve Araştırma Hastanesi, Pediatrik Cerrahi Kliniği, Mogadishu
}

Dergiye Ulaşma Tarihi: 09.08.2019 Dergiye Kabul Tarihi: 30.09.2019 Doi 10.5505/aot.2019.82335

\section{ÖZET}

İnfantil hemanjioendotelyoma, batında kitle veya hepatomegali ile bulgu veren karaciğerin nadir görülen benign vasküler bir tümörüdür. Malign bir lezyon olmadığı halde klinik olarak çok ciddi semptomlara neden olabilir. $\mathrm{Bu}$ nedenle doğru tanı, uygun tedavi için çok önemlidir. Bu yazıda multipl hepatik infantil hemanjioendotelyoma tanılı 6 aylık bir hastanın ultrasonografi ve BT bulguları ile sunulması amaçlandı.

Anahtar Kelimeler: karaciğer, infantil hemanjioendotelyoma, BT, ultrasonografi

\begin{abstract}
Infantile hemangioendothelioma is a rare benign vascular tumor of the liver which generally presenting an abdominal mass or hepatomegaly. Although it is considered a benign lesion it can cause clinically very serious symptoms. Therefore, correct diagnosis is very important for proper treatment. The case of a 6-month-old female patient with multiple hepatic infantile hemangioendotheliomas is reported with ultrasonographic and CT findings.
\end{abstract}

Keywords: liver, infantile hemangioendothelioma, CT, ultrasonography

\section{INTRODUCTION}

Infantile hemangioendothelioma (IHE) is a rare liver tumor that can be seen in infants (1). It can be multiple or a single lesion in the liver (2). In most of the cases, it presents before 6 months of age (3). It is more common in females (4). Generaly the presenting signs are an abdominal mass or hepatomegaly. Although it is considered not to be a malignant lesion it can cause clinically very serious symptoms (5). Therefore, correct diagnosis is very important for proper treatment. In the past, liver biopsy and angiography were frequently used to establish the diagnosis. However, with the improvement of ultrasonography, CT and MRI, diagnosis of the disease by using noninvasive imaging modalities became possible.

\section{CASE REPORT}

A 6 - month - old black female patient was referred to our hospitals pediatric surgery department from another hospital with a diagnosis of liver masses. The parents said that she had complaints of weakness and abdominal distention for two weeks. Physical examination revealed massive hepatomegaly and abdominal mass. In our radiology department contrastenhanced dynamic abdominal CT scan, taken in the previous hospital, was evaluated. Then doppler ultrasonography was performed to evaluate the sonographic appearance and vascularity of the lesions.

CT examination revealed that the liver enlarged and extended into the pelvis on the right and posterior to the spleen on the left. Multiple lesions of different sizes ( 8 to $49 \mathrm{~mm}$ ) were seen in the liver causing lobulation in the contour of both lobes. All lesions were unencapsulated but well circumscribed. After an overview of CT, all phases were examined sequentially.

On non-contrast CT, the lesions were homogeneous and hypodense accorting to the liver parenchyma. No calcification was observed in the lesions (figure 1). 
Unfortunately, the parameters such as the volume and the administration rate of the contrast agent and the starting seconds of the arterial phase were not known because of the examination was not performed in our centre. In contrast-enhanced phases, the liver lesions show two different enhancement patterns according to their size.

Lesions less than $20 \mathrm{~mm}$ in size were homogeneously enhanced in the first phase (arterial) and lesions greater than $20 \mathrm{~mm}$ in size showed intense enhancement outside the central part (figure 2). In the second phase (venous), 75 seconds after the end of the arterial phase, it was observed that all lesions continued to retain contrast, whereas lesions greater than $20 \mathrm{~mm}$ continued to central enhancement (figure 3 ). In the third phase (late phase), which started 280 seconds after the end of the second phase, all lesions were fully enhanced (figure 4).

The abdominal aortic diameter was narrowed below the level of the celiac artery. CT showed dilated common hepatic artery and tortuous dilated hepatic artery branches extending to the lesions. Additionally intrahepatic portal vein and hepatic vein branches were observed dilated due to arteriovenous shunts. The thoracic images showed enlargement of the heart. On CT scan no other lesion metastasize to the liver existed. Ultrasonographic examination showed multipl homogeneous hypodense lesions in the liver. Color doppler examination revealed that the lesions were hypervascular (figure 5). Enlargement of the parenchymal arterial and venous structures and increased blood flow were also observed.

Doppler Ultrasonography and contrastenhanced CT findings of the patient with normal alpha-fetoprotein (AFP) values were consistent with infantile hemangioendothelioma(IHH).

The patient died due to heart failure in a short time. The parents provided permission for publication of this case reports.

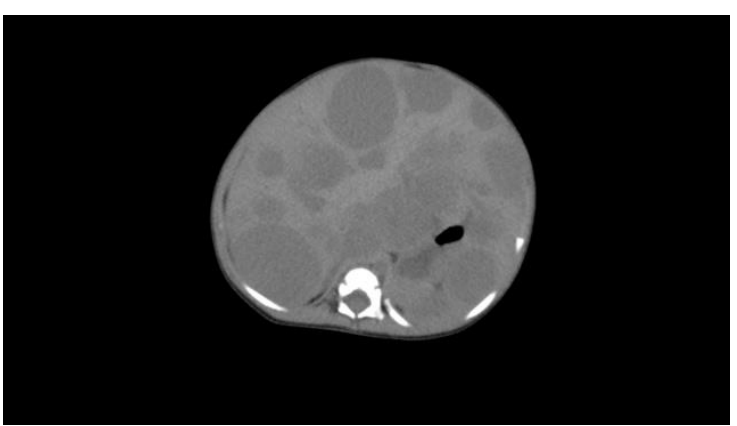

Figure 1: Non-contrast phase: the lesions were homogeneous, hypodense and without calcification.

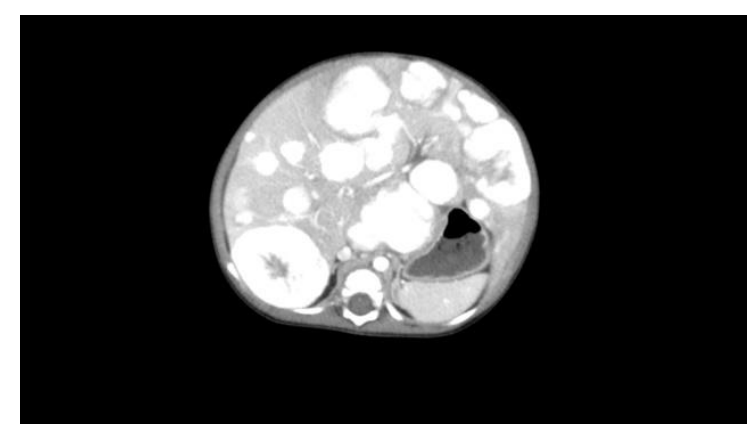

Figure 2: Arterial phase: Lesions less than 20 $\mathrm{mm}$ in size were homogeneously enhanced in the arterial phase and lesions greater than 20 $\mathrm{mm}$ in size showed intense enhancement outside the central part.

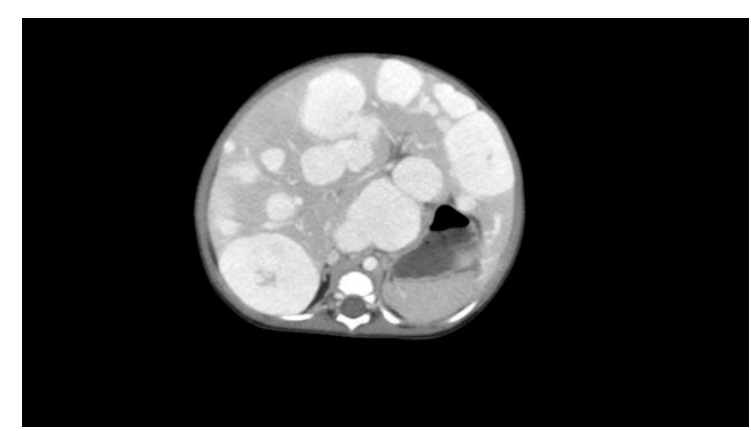

Figure 3:Venous phase: All lesions continued to retain contrast, whereas lesions greater than $20 \mathrm{~mm}$ continued to central enhancement.

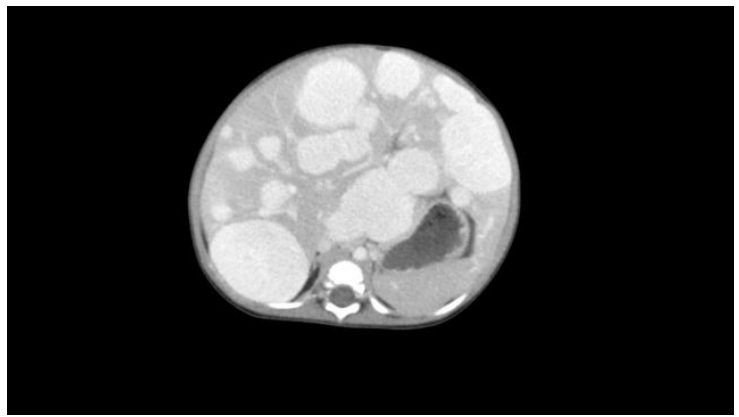

Figure 4: Late phase: All lesions were fully enhanced. 


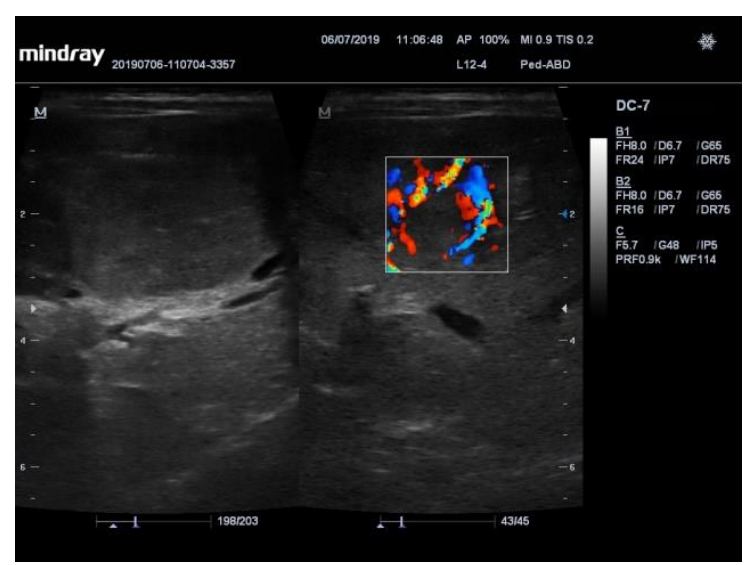

Figure 5: Doppler ultrasound showing a hypoechoic echo pattern with prominent vascularity in the mass.

\section{DISCUSSION}

$\mathrm{IHH}$, the most common benign tumor of the liver in children, is seen almost exclusively in the first 6 months of life $(4,6)$. Females are more frequently affected and there is no racial predilection $(1,6)$. The clinical manifestation of $\mathrm{IHH}$ is variable. The tumor may be asymptomatic and discovered incidentally. More often, the tumor is large and manifests as hepatomegaly, abdominal distention, or a palpable abdominal mass $(2,8)$. Patients with IHH usually have a good prognosis, espacialy some of them regresses gradually over several months. Nevertheless, infants may die due to associated complications such as congestive heart failure, arteriovenous shunting, and coagulopathy $(7,8)$. Therefore, diagnosis is very important for appropriate treatment plan. It has been reported that IHH is usually well demarcated from surrounding liver tissue (2, 3 ). Ultrasonography may show solitary or multiple lesions with hypoechoic echo-texture. On doppler examination, lesions are hypervascular $(2,3)$. Hepatic artery, portal vein and hepatic veins have increased flow due to intralesional arteriovenous shunts (2). Dilation occurs especially in the parenchymal branches of the hepatic artery. On unenhanced CT, IHH usually manifests as a well-defined mass that is hypoattenuating relative to the normal liver parenchyma $(2,3)$. On contrast-enhanced CT, the enhancement pattern may resemble that of an adult hemangioma, with peripheral puddling of contrast material in the early phase and central enhancement with variable delay $(2,3)$.
The differential diagnosis of an infant liver mass should include IHH, cavernous hemangioma, hepatoblastoma, mesenchymal hamartoma, and metastatic neuroblastoma $(2,3)$. Because the morphologic and hemodynamic characteristics of cavernous hemangioma may be similar or identical to those of $\mathrm{IHH}$, the radiological findings may also be identical. But hepatic cavernous hemangioma is rare in patients younger then one year old.

The most important differential diagnosis to $\mathrm{IHH}$ in this age group is hepatoblastoma (HBL). The serum AFP level is found elevated up to $90 \%$ of patients with HBL $(2,3)$. The lesions are usually large and solitary. On ultrasonography, HBL most often demonstrates heterogeneous echogenicity owing to hemorrhage or necrosis $(2,3)$. On non-contrast CT, HBL shows irregular marginated hypodense lesions and some of them with fine and granular calcifications. Contrast-enhanced CT typically demonstrates inhomogeneous intratumoral enhancement that is generally less dense then the normal liver parenchyma $(2,3)$. In this patient, the AFP value was normal, the lesions were demonstrates homogeneous echogenicity on ultrasonography, and noncontrast CT showed well marginated lesions without calcification, and contrast-enhanced CT showed different enhancement patterns from HBL.

The absence of large cystic components excluded the rare mesenchymal hamartoma and there was no radiologic evidence of metastatic lesions such as neuroblastoma.

In our hospital, we do not perform multiphase CT for pediatric patients due to high radiation dose. If a dynamic examination is required for diagnosis, we usually prefer dynamic MRI. We ask all patients admitted to our hospital, especially because we are a reference hospital, whether they have previous radiological examinations. The previous CT of this patient was adequate for diagnosis.

As a conclusion, the IHH may often be diagnosed based on imaging, and laboratory findings.

Çıkar Çatışması Beyanı: Yazarlar çıkar çatışması olmadığını bildirmişlerdir. 
Finansal Destek: Bu çalışma her hangi bir fon tarafından desteklenmemiştir.

\section{REFERANSLAR}

1. Wang T, Wang Y, Liang Y, Lu G. Infantile Hepatic Hemangioendothelioma Associated With Congestive Heart Failure: Two Case Reports With Different Outcomes. Medicine (Baltimore). 2015;94(52):e2344. doi:10.1097/MD.0000000000002344

2. Kaniklides C, Dimopoulos P A, Bajic D, Infantil Hemangioendothelioma: A case report, Acta Radiologica 41 (2000) 161-164

3. Singh AP, Gupta A, Mathur V, Barolia DK. Hepatoblastoma misdiagnosed as infantile hemangioendothelioma in a child - a case report. Menoufia Medical Journal 2019, 31:14791481
4. Güldür M E, Çeçe H, Yılmaz L E ve Ark, İnfantil Hepatik Hemanjioendotelyoma: Olgu Sunumu, Van Tip Dergisi: 20(3): 154-157, 2013

5. Şenol S, Yörük A, Kuru İ, Kıral A, Ersoy G, Diffuse fatal infantile hemangioendothelioma in an infant liver: Case report, Journal of Clinical and Experimental Investigations 2015; 6 (3): 312-314 doi: 10.5799/ahinjs.01.2015.03.0540

6. Özdemir Ö, Özdemir M, Akın M İ, Yörük A, Şenyüz $O \quad F$, İnfantil hepatik "hemanjiyoendotelyoma"lı bebeğin cerrahi ile başarılı tedavisi Çocuk Cerrahisi Dergisi 26(12):55-60, 2012

7. Alt-Tonbary Y, Fouda A Infantile hepatic hemangioendothelioma: an 8-month old infant successfully treated with a corticosteroid hematol oncol stem cell ther 2009; 2(3): 422-425

8. Tuysuz G, Tayfun F, Goya C. Steroidresistant infantile hepatic hemangioendothelioma successfully treated with propranolol. J Clin Neonatol 2016;5:140-1. 